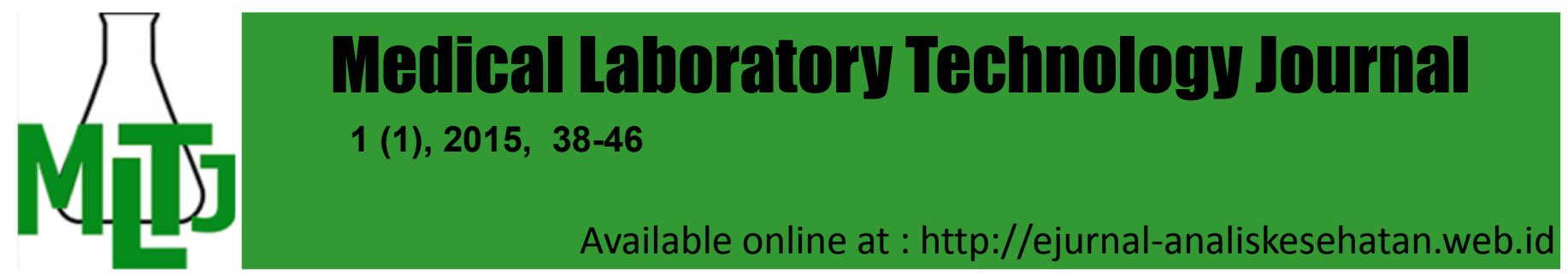

\title{
PEWARNAAN GRAM BUFFY COAT UNTUK DETEKSI AWAL PASIEN BAKTEREMIA
}

\author{
Leka Lutpiatina \\ Jurusan Analis Kesehatan Poltekkes Kemenkes Banjarmasin \\ JI Mistar Cokrokusumo 4a Banjarbaru \\ e-mail: leka.zns@gmail.com
}

\begin{abstract}
Bacteremia is one public health problem. Bacteremia was ranked as the tenth leading cause of death in the United States. Gram staining of buffy coat can be used for early detection of patients with bacteremia. Rapid diagnostic tests with these Gram staining can be interpreted within an hour and the research that has been conducted Richmond et al. 2002, have a sensitivity of $75 \%$ and specificity of $79 \%$. This study aimed to study the sensitivity and specificity of Gram buffy coat with the gold standard blood culture media biphasic fever suspected patients. This study was an observational study with cross sectional study. The study population was suspected fever patients in hospitals Ratu Zalecha Martapura months from March to May 2013. The samples were suspect fever patients in hospitals Queen Zalecha Martapura March-May 2013 were taken by purposive with the inclusion criteria: Patients District General Hospital Ratu Zalecha Martapura, aged $\geq 10$ years, had fever $\geq 5$ days, had symptoms of abdominal pain, willing to follow the study. Gram staining microscopic results were analyzed by application epicalc. Microscopic results buffy coat Gram staining Gram-negative rods are found as many as seven $(26 \%)$ and were not found Gram-negative rods as many as $20(74 \%)$. Culture results of this study are Gram negative bacterial growth as much as $6(22 \%)$ and no growth as many as $21(78 \%)$. Conclusion The results of microscopic Gram stain buffy coat has a value of $67 \%$ sensitivity and $86 \%$ specificity.
\end{abstract}

Keywords: Gram stain, Buffy Coat, bacteraemia

Abstrak: Bakteremia adalah salah satu masalah kesehatan masyarakat. Bakteremia menempati peringkat kesepuluh sebagai penyebab utama kematian di Amerika Serikat (Kung H et.al., 2008). Pewarnaan Gram dari buffy coat dapat digunakan untuk deteksi awal pasien bakteremia. Tes diagnostik yang cepat dengan pewarnaan Gram ini dapat di interpretasikan dalam waktu satu jam dan dalam penelitian yang telah dilakukan Richmond et al. 2002, mempunyai sensitifitas $75 \%$ dan spesifisitas $79 \%$. Penelitian ini dimaksudkan untuk mempelajari sensitifitas dan spesifisitas pewarnaan Gram buffy coat dengan gold standar kultur darah media bifasik pada pasien tersangka demam. Penelitian ini merupakan penelitian observasional dengan rancangan cross sectional study. Populasi penelitian adalah pasien tersangka demam di RSUD Ratu Zalecha Martapura bulan Maret-Mei 2013. Sampel penelitian adalah pasien tersangka demam di RSUD Ratu Zalecha Martapura bulan Maret-Mei 2013 yang diambil secara purposive dengan Kriteria inklusi : Pasien Rumah Sakit Umum Daerah Ratu Zalecha Martapura, berumur $\geq 10$ tahun, memiliki gejala demam $\geq 5$ hari, memiliki gejala sakit perut, bersedia mengikuti penelitian. Hasil mikroskopis pewarnaan Gram dianalisis dengan aplikasi epicalc. Hasil mikroskopis pewarnaan Gram buffy coat yaitu ditemukan batang Gram negatif sebanyak 7 (26\%) dan yang tidak ditemukan batang Gram negatif sebanyak 20 (74\%). Hasil kultur penelitian ini terdapat pertumbuhan bakteri Gram negatif sebanyak 6 (22\%) dan tidak terdapat pertumbuhan sebanyak 21 (78\%). Kesimpulan hasil mikroskopis pewarnaan Gram buffy coat mempunyai nilai sensitifitas $67 \%$ dan spesifisitas $86 \%$.

Kata kunci : Pewarnaan Gram, Buffy Coat, Bakteremia

Copyright (C) 2015, MLTJ, ISSN 2461-0879 


\section{PENDAHULUAN}

Demam adalah manifestasi sistemik yang paling sering terjadi pada respons radang dan merupakan gejala utama penyakit infeksi. Zatzat yang dapat menimbulkan demam (pirogen) antara lain adalah endotoksin bakteri gram negatif dan sitokin yang dilepaskan dari sel-sel limfoit, seperti interleukin-1(Jawezt et al., 2010).

Berbagai aktivator dapat merangsang fagosif monoluklear dan sel-sel lain untuk melepaskan inerleukin-1. Aktivator-aktivator tersebut diantaranya adalah mikroba dan produknya; toksin, termasuk endotoksin; kompleks antigen antibodi; proses radang; dan lain-lain. Interleukin-1 dibawa aliran darah ke pusat pengatur suhu di hipotalamus, mencetuskan respons fisiologik yang menyebabkan demam, misalnya peningkatan produk panas, pengeluaran panas yang berkurang (Jawezt et al., 2010).

Jenis - jenis demam diantaranya adalah demam berkepanjangan (Prolonged fever) yaitu demam berlangsung lebih lama dari sekitar 10-14 hari. Penyebab demam berkepanjangan antara lain karena Infeksi bakteri, virus atau jamur, misalnya endokarditis infektif, demam tifoid, tuberkulosis atau infeksi jangka panjang lainnya (Colin Tidy, 2013).

Infeksi karena bakteri yang menimbulkan demam dapat mempengaruhi hampir semua sistem organ dalam tubuh, yaitu sistem saraf pusat, sistem pernafasan, sistem pencernaan, sistem urogenital dan sistem peredaran darah. Sistem peredaran darah (termasuk jantung dan paru-paru) dapat diserang oleh bakteri dengan gejala demam, nyeri tubuh, menggigil, kelemahan, atau kebingungan. Kondisi yang disebut dengan sepsis terjadi ketika bakteri memasuki aliran darah (Davis CP, 2013).

Infeksi bakteri dimulai pada saat bakteri masuk ke dalam tubuh dan melekat pada sel epitel sehingga menjadi tempat infeksi primer. Bakteri-bakteri memperbanyak diri dan menyebar langsung ke aliran darah melalui jaringan atau sistem limfatik. Infeksi tersebut diistilahkan sebagai bakteremia yang dapat bersifat sementara atau persisten. Bakteremia memungkinkan bakteri menyebar luas ke dalam tubuh dan mencapai jaringan yang cocok untuk multiplikasinya (Jawezt et al.,
2010).

Bakteremia adalah salah satu masalah kesehatan masyarakat. Bakteremia menempati peringkat kesepuluh sebagai penyebab utama kematian di Amerika Serikat (Kung $\mathrm{H}$ et.al., 2008). Insiden bakteremia telah meningkat selama dekade terakhir dan umumnya disebabkan oleh komplikasi pasca operasi, kateter intravaskular dan, infeksi lokal yang rumit (Odetola et al. 2003 ; Gura, 2004). Mortalitas pasien secara keseluruhan sebanyak $20 \%$ dan pasien dengan syok septik dan kegagalan organ sebanyak 90\% (Segal \& Chamberlain 2000 ; Bearman \& Wenzel 2005).

Perkiraan kejadian bakteremia pada studi di Finlandia berkisar 125 kasus per 100.000 orang pertahun (Skogberg K.,et al., 2008) dan 189 kasus per 100.000 orang pertahun di Olmsted County, Minnesota (Uslan DZ et.al., 2007). Prevalensi pasien bakteremia di Denmark bagian utara dengan tingkat morbiditas tinggi meningkat dari $19,8 \%$ selama 1992-1996 menjadi 29,7\% selama 2002- 2006. Proporsi bakteremia Gram negatif meningkat antara periode 1992-1996 dan periode 20022006, sedangkan proporsi bakteremia Gram positif menurun antara periode 1992-1996 dan periode 2002-2006 (Sogaard M, et.al., 2013).

Bakteri yang dapat menyebabkan demam diantaranya adalah bakteri penyebab infeksi sistem gastrointestinal (sistem pencernaan) seperti Salmonella, Escherichia coli, Klebsiella dan Serratia. Infeksi oportunistik yang disebabkan bakteri genus Pseudomonas juga dapat menimbulkan demam.

Demam tifoid yang disebabkan oleh salmonella merupakan salah satu penyakit karena infeksi bakteri. Demam tifoid menjadi salah satu masalah kesehatan dunia. Demam tifoid terjadi baik di negara tropis maupun negara subtropis, terlebih pada negara berkembang. Besarnya angka kejadian demam tifoid sulit ditentukan karena mempunyai gejala dengan spektrum klinis yang luas (Muliawan \& Surjawidjaya 1999). Data Centres for disease Control and Prevention (CDC) demam tifoid masih umum di negara berkembang, dengan kasus sekitar 21,5 juta orang setiap tahun (CDC, 2010). 
Kasus demam tifoid ini tersebar secara merata di seluruh propinsi di Indonesia dengan insidensi daerah pedesaan 358/100.000 penduduk/tahun dan daerah perkotaan 760/100.000 penduduk/ tahun atau sekitar 600.000 dan 1.5 juta kasus per tahun (Parry, 2002). Rekam medik Rumah Sakit Umum Ratu Zalecha mencatat kasus demam tifoid tahun 2011 sebanyak 2,6\% dan tahun 2012 sebanyak $2,0 \%$ dari jumlah pasien keseluruhan. Data Hasil Riset Dasar Kesehatan (RISKESDAS) tahun 2007, demam tifoid menyebabkan $1,6 \%$ kematian penduduk Indonesia pada semua umur (Depkes RI, 2008).

Manifestasi klinis demam tifoid tidak khas dan sangat bervariasi sesuai dengan patogenesis demam tifoid (Ashkenazy \& Cleary, 2000). Penentuan diagnosis pasti dari penyakit ini diperlukan pemeriksaan laboratorium. Pemeriksaan laboratorium yang dapat digunakan adalah pemeriksaan darah tepi, pemeriksaan bakteriologis dengan isolasi dan biakan bakteri, uji serologis, dan pemeriksaan bakteri secara molekuler (Karsinah et al.,, 1994; Tumbelaka, 2005).

Kultur merupakan gold standard dalam menegakkan diagnosis demam tifoid (Karsinah et al.,, 1994). Kultur darah dengan hasil biakan yang positif memastikan demam tifoid (Widodo D, 2009). Biakan darah terhadap Salmonella juga tergantung dari saat pengambilan pada perjalanan penyakit. Beberapa peneliti melaporkan biakan darah positif $40-80 \%$ atau $70-90 \%$ dari pasien pada minggu pertama sakit dan positif $10-50 \%$ pada akhir minggu ketiga (WHO, 2003; Tumbelaka, 2005). Sensitivitasnya akan menurun pada sampel pasien yang telah mendapatkan antibiotika dan meningkat sesuai dengan volume darah dan rasio darah dengan media kultur yang dipakai (Parry, 2002).

Kultur darah adalah salah satu prosedur yang paling sensitif untuk mendeteksi bakteri dalam darah. Diagnosis bakteremia dengan menggunakan kultur darah telah dianggap sebagai standar emas selama bertahun-tahun (Shafazand \& Weinacker 2002).

Pemeriksaan kultur mempunyai spesifisitas yang tinggi tetapi sensitivitasnya rendah dan adanya kendala berupa lamanya waktu yang dibutuhkan (5-7 hari) serta peralatan yang lebih canggih untuk identifikasi bakteri sehingga tidak praktis (Pawitro, Noorvitry \& Darmowandowo 2002; Tumbelaka 2005). Tes yang ideal untuk suatu pemeriksaan laboratorium seharusnya bersifat sensitif, spesifik dan cepat diketahui hasilnya (Bakr et al., 2011). Kegagalan dalam isolasi/ biakan dapat disebabkan oleh keterbatasan media yang digunakan (WHO, 2003; Wain et al., 2001).

Modifikasi media Triple Sugar Iron Agar (TSIA) yang berupa media padat dan Tryptic Soy Broth (TSB) yang berupa media cair diharapkan dapat meningkatkan pertumbuhan bakteri. Media cair TSB mengandung pepton kasein dan pepton kedelai yang kaya asam amino, senyawa nitrogen, kalsium dan fosfor. Media cair TSB ini juga diharapkan dapat melisiskan sel fagosit. Media padat agar miring TSIA diharapkan dapat menampung pertumbuhan bakteri pada media cair sehingga pada permukaan media padat tumbuh koloni karakteristik yang mudah dideteksi dan dilakukan identifikasi. Media bifasik ini diharapkan dapat lebih cepat mendeteksi pertumbuhan bakteri pada specimen darah.

Buffy coat adalah lapisan tipis di bagian tengah darah yang disentrifugasi. Lapisan ini berwarna putih abu-abu dan mengandung leukosit dan trombosit yang diapit oleh lapisan plasma yang ringan dan lapisan eritrosit yang lebih berat (Richmond et al., 2002).

Pewarnaan Gram dari buffy coat dapat digunakan untuk deteksi awal pasien bakteremia. Tes diagnostik yang cepat dengan pewarnaan Gram ini dapat di interpretasikan dalam waktu satu jam dan dalam penelitian yang telah dilakukan Richmond et al. 2002, mempunyai sensitifitas $75 \%$ dan spesifisitas $79 \%$.

Penelitian ini dimaksudkan untuk mempelajari sensitifitas dan spesifisitas pewarnaan Gram buffy coat terhadap kultur darah menggunakan media bifasik pada pasien tersangka demam. Hasil penelitian ini diharapkan dapat diterapkan sebagai tes yang akurat untuk diagnosa demam. 


\section{BAHAN DAN METODE}

Penelitian ini merupakan penelitian observasional dengan rancangan cross sectional study. Populasi penelitian ini adalah pasien tersangka demam di RSUD Ratu Zalecha Martapura bulan Maret-Mei 2013. Sampel penelitian ini adalah pasien tersangka demam di RSUD Ratu Zalecha Martapura bulan MaretMei 2013 yang diambil secara purposive dengan Kriteria inklusi Pasien Rumah Sakit Umum Daerah Ratu Zalecha Martapura, berumur $\geq 10$ tahun, memiliki gejala demam $\geq 5$ hari, memiliki gejala sakit perut, bersedia mengikuti penelitian. Kriteria eksklusi : Pasien menderita malaria, pasien menderita demam berdarah, pasien yang fisiknya sangat lemah. Jumlah sampel sebanyak 27 pasien.

Penelitian dilaksanakan di Laboratorium Mikrobiologi Jurusan Analis Kesehatan Politeknik Kesehatan Kemenkes Banjarmasin dan laboratorium RSUD Ratu Zalecha Martapura pada bulan Maret-Juni 2013.

\section{Prosedur kultur darah media bifasik}

Diambil $5 \mathrm{ml}$ darah kemudian di inokulasikan pada media agar bifasik Inkubasi suhu $37^{\circ} \mathrm{C}$ selama 1-7 hari. Positif apabila terlihat kekeruhan dan tumbuh koloni dengan karakteristik smooth, tidak berwarna, diameter 1-4 $\mathrm{mm}$ dengan atau tanpa $\mathrm{H}_{2} \mathrm{~S}$, konfirmasi dengan pemeriksaan mikroskopis pewarnaan Gram. Identifikasi dengan uji biokimia dan uji serologi. Negatif apabila tidak terjadi pertumbuhan setelah 7 hari.

\section{Prosedur pewarnaan Gram}

Buat sediaan pada objek gelas, keringkan, kemudian rekatkan (fiksasi) $3 x$ di atas api bunsen. Tuangi dengan aquades biarkan selama 5 menit, buang larutan. Tuangi dengan larutan karbol-gentian-violet, biarkan selama 5 menit. Zat warna dibuang dan bubuhi dengan larutan mordant (lugol), diamkan selama kira-kira 1-3 menit. Lugol dibuang dan preparat dicelupkan ke dalam alkohol 96\%, sampai warna gentian violet lepas (sampai gentian violet tidak ada luntur lagi). Cuci dengan air kran sampai bersih, kemudian bubuhi dengan cat-penutup (counter stain) larutan water-fuchsin, biarkan kira-kira 1-2 menit.Cuci dengan air kran, keringkan pada temperatur kamar, lihat dengan mikroskop memakai lensa rendam minyak. Gram positif berwarna ungu. Gram negatif berwarna merah (Joubori S, 2006)

Hasil mikroskopis pewarnaan Gram dianalisis dengan aplikasi epicalc.

\section{HASIL DAN PEMBAHASAN}

Penelitian ini telah dilakukan pada 27 sampel darah dari 27 pasien di RSUD Ratu Zalecha Martapura pada bulan Maret sampai dengan Mei 2013. Hasil mikroskopis pewarnaan Gram buffy coat yaitu ditemukan batang Gram negatif sebanyak 7 (26\%) dan yang tidak ditemukan batang Gram negatif sebanyak 20 (74\%).

Hasil kultur penelitian ini terdapat pertumbuhan bakteri Gram negatif sebanyak 6 (22\%) dan tidak terdapat pertumbuhan sebanyak $21(78 \%)$, hasil yang lebih jelas dapat dilihat pada tabel 1. Jenis bakteri Gram negatif yang tumbuh pada darah agar bifasik dapat dilihat pada tabel 2.

Hasil uji serologi Widal dapat dilihat pada tabel 3, sedangkan hasil uji serologi Widal pasien tersangka demam dengan hasil kultur darah agar bifasik positif dapat dilihat pada tabel 4. Hasil mikroskopis pewarnaan Gram dari buffy coat dan hasil kultul darah agar bifasik pasien tersangka demam dapat dilihat pada tabel 5 .

Tabel 1. Hasil proporsi bakteri Gram negatif pada kultur darah agar bifasik pasien tersangka demam

\begin{tabular}{cc}
\hline Hasil kultur & Jumlah $(\%)$ \\
\cline { 2 - 2 } & Kultur darah agar bifasik \\
\hline Ada pertumbuhan & $6(22)$ \\
\hline Tidak ada pertumbuhan & $21(78)$ \\
\hline
\end{tabular}


Tabel 2. Jenis bakteri Gram negatif hasil kultur darah agar bifasik pasien tersangka demam

\begin{tabular}{cc}
\hline Bakteri & Jumlah isolat positif \\
\cline { 2 - 2 } & \\
\hline E.coli & 1 \\
Serratia sp & 2 \\
\hline Klebsiella. sp & 2 \\
Pseudomonas. sp & 1 \\
\hline
\end{tabular}

Tabel 3. Hasil uji serologi Widal pasien tersangka demam

\begin{tabular}{lcccc}
\hline $\begin{array}{l}\text { Hasil } \\
\text { Widal }\end{array}$ & $\begin{array}{c}\text { S.thypi } \\
\text { Antigen } \\
\mathrm{n}(\%)\end{array}$ & $\begin{array}{c}\text { S.thypi } \\
\text { Antigen H } \\
\mathrm{n}(\%)\end{array}$ & $\begin{array}{c}\text { S.parathypi A } \\
\text { Antigen O } \\
\mathrm{n}(\%)\end{array}$ & $\begin{array}{c}\text { S.parathypi B } \\
\text { Antigen O } \\
\mathrm{n}(\%)\end{array}$ \\
\hline Negatif & $6(22)$ & $9(33)$ & $13(48)$ & $10(37)$ \\
\hline $1: 80$ & $7(26)$ & $3(11)$ & $8(30)$ & $7(26)$ \\
\hline $1: 160$ & $5(19)$ & $9(33)$ & $3(11)$ & $3(11)$ \\
\hline $1: 320$ & $9(33)$ & $6(22)$ & $3(11)$ & $7(26)$ \\
\hline
\end{tabular}

Keterangan : Angka menunjukkan titer antibodi

Tabel 4 Hasil uji serologi Widal pasien tersangka demam dengan hasil kultur darah agar bifasik positif

\begin{tabular}{lcccc}
\hline Jenis bakteri (no.sampel) & $\begin{array}{c}\text { S.thypi } \\
\text { Antigen O } \\
\text { (titer) }\end{array}$ & $\begin{array}{c}\text { S.thypi } \\
\text { Antigen H } \\
\text { (titer) }\end{array}$ & $\begin{array}{c}\text { S.parathypi A } \\
\text { Antigen O } \\
\text { (titer) }\end{array}$ & $\begin{array}{c}\text { S.parathypi } \\
\text { B } \\
\text { Antigen O } \\
\text { (titer) }\end{array}$ \\
\hline E. coli, no sampel 8 & $1: 320$ & $1: 320$ & $1: 320$ & $1: 320$ \\
\hline Serratia sp, no sampel 12 & $1: 80$ & $1: 80$ & $1: 160$ & - \\
\hline Klebsiella sp, no sampel 16 & $1: 320$ & $1: 160$ & $1: 80$ & $1: 320$ \\
\hline $\begin{array}{l}\text { Pseudomonas sp, no } \\
\text { sampel 18 }\end{array}$ & $1: 80$ & - & - & $1: 80$ \\
\hline Serratia sp, no sampel 21 & $1: 80$ & $1: 160$ & - & - \\
\hline Klebsiella sp, no sampel 24 & $1: 320$ & $1: 160$ & - & $1: 80$ \\
\hline
\end{tabular}

Keterangan : Angka menunjukkan titer antibodi

Tabel 5. Hasil mikroskopis pewarnaan Gram dari buffy coat dan hasil kultur darah agar bifasik pasien tersangka demam

\begin{tabular}{lccc}
\hline \multicolumn{1}{c}{ Pewarnaan Gram } & \multicolumn{3}{c}{ Kultur darah agar bifasik } \\
\cline { 2 - 5 } & $\begin{array}{c}\text { Terdapat } \\
\text { pertumbuhan } \\
\text { bakteri }\end{array}$ & $\begin{array}{c}\text { Tidak terdapat } \\
\text { pertumbuhan bakteri }\end{array}$ & Total \\
\hline Ditemukan bakteri Gram (-) & 4 & 3 & 7 \\
\hline $\begin{array}{l}\text { Tidak ditemukan bakteri Gram } \\
(-)\end{array}$ & 2 & 21 & 20 \\
\hline Total & 6 & & 27 \\
\hline
\end{tabular}


Uji diagnostik dari data tersebut menghasilkan nilai sensitifitas sebesar $67 \%$, spesifisitas $86 \%$, nilai duga positif $57 \%$, dan nilai duga negatif $90 \%$.

\section{Hasil Mikroskopis Pewarnaan Gram Buffy Coat}

Hasil mikroskopis pewarnaan Gram buffy coat dibanding hasil kultur darah agar bifasik mempunyai nilai sensitifitas, spesifisitas, nilai duga positif, nilai duga negatif, secara berturutturut adalah $67 \%, 86 \%, 57 \%, 90 \%$. Hal ini tidak berbeda jauh dengan penelitian yang dilakukan oleh Richmond et al. 2002, yang mempunyai sensitifitas $75 \%$ dan spesifisitas $79 \%$, nilai duga positif $43 \%$ dan nilai duga negatif $94 \%$.

Mikroskopis pewarnaan Gram buffy coat dengan hasil negatif terdapat pada dua sampel dengan hasil kultur positif, konsentrasi yang besar dari bakteri dalam sampel diperlukan untuk dapat terlihat dalam pemeriksaan mikroskopis. Konsentrasi bakteri dalam darah yang dapat divisualisasikan harus mencapai > $4 \times 10^{3} \mathrm{cfu} / \mathrm{ml}$ (Richmond et al. 2002). Hasil positif dengan terlihatnya batang Gram negatif pada pewarnaan Gram tetapi tidak diiringi dengan pertumbuhan koloni pada kultur dapat menandakan ditemukannya bakteri yang tidak viable (hidup) didalam preparat Gram.

Kegunaan pewarnaan Gram dari buffy coat sebagai alat yang cepat dalam mendeteksi bakteremia pada pasien dewasa yang mengalami tanda dan gejala klinis sepsis telah dibuktikan (Richmond et al. 2002). Metode pewarnaan Gram dari buffy coat dan kultur dengan menggunakan darah perifer yang ditampung pada tabung hematokrit kapiler, juga telah menghasilkan prosedur diagnosis dini bayi bakteremia dan septikemia (Joubori S, 2006).

\section{Hasil Pemeriksaan Kultur}

Hasil penelitian ini tidak ditemukan pertumbuhan Salmonella, tetapi terdapat pertumbuhan bakteri Gram negatif lain yaitu $E$. Coli, pseudomonas. sp, Serratia. sp dan klebsiella sp. Penelitian yang dilakukan oleh Zulfikar A. Butta (2006) menemukan bahwa kultur darah mempunyai nilai keberhasilan sebesar 40-80\%. Keberhasilan memperoleh isolat S.typhi dari kultur darah widal positif sebesar 10,74\% (Amarantini et al.2009). Penelitian Damayanti et al. pada pasien dengan hasil widal positif dilakukan kultur darah sebanyak 136 sampel dengan hasil 60 sampel $(44,1 \%)$ kultur darah positif, terdiri dari 44 sampel $(32,4 \%)$ positif Staphylococcus sp. dan 16 sampel $(11,8 \%)$ positif bakteri batang Gram negatif anggota familia Enterobacteriaceae yaitu: Enterobacter cloacae, Salmonella typhi, Serratia marcescens, Escherichia coli, Salmonella ssp., Klebsiella ssp. (Damayanti S, et al., 2012). Hal ini menunjukkan adanya jenis bakteri lain selain Salmonella. typhi pada kultur darah widal positif.

Penelitian yang serupa dilakukan oleh Itah dan Uweh (2005) pada 100 pasien tersangka demam, ditemukan bakteri pada $39 \%$ sampel yaitu Staphylococcus aureus, Escherichia coli, Streptococcus faecalis, Pseudomonas aeruginosa, Klebsiella pneumoniae, Proteus vulgaris dan Salmonella typhi. Frekuensi bakteri yang tertinggi dalam sampel darah adalah Staphylococcus aureus $35,9 \%$ diikuti oleh Escherichia coli 15,4\%, sedangkan pseudomonas aerogenosa 11\%, Klebsiella pneumoniae $13 \%$ dan Salmonella typhi $10 \%$ (itah \& uweh, 2005). Hal ini menunjukkan kecilnya frekuensi ditemukannya Salmonella pada pasien tersangka demam. Penelitian yang dilakukan ini menggunakan 27 sampel, sehingga terdapat kemungkinan masih belum ditemukannya Salmonella, dan hanya ditemukan bakteri Gram negatif lain yang frekuensinya lebih tinggi sesuai dengan penelitian yang dilakukan Itah dan Uweh.

Daerah endemik memiliki nilai keberhasilan kultur darah yang lebih rendah, hal ini kemungkinan karena tingginya penggunaan antibiotik (Butta ZA, 2006). Rekam medik Rumah Sakit Umum Ratu Zalecha mencatat kasus demam pada tahun 2011 sebanyak 2,6\% dan tahun 2012 sebanyak $2,0 \%$ dari jumlah pasien keseluruhan. Tingginya kasus demam ini juga sesuai Informasi dokter poliklinik Rumah Sakit Umum Ratu Zalecha Martapura yang juga menyatakan bahwa pasien yang berobat ke Rumah Sakit, rata-rata sebelumnya telah melakukan pengobatan di puskesmas terdekat dan telah mengkonsumsi antibiotik. Hal ini juga 
menjelaskan hasil negatif pertumbuhan Salmonella pada penelitian.

Organisme yang ketika terisolasi dari kultur darah yang dianggap sebagai penyebab bakteremia atau fungemia adalah termasuk Staphylococcus aureus, Streptococcus pneumoniae, Escherichia coli dan Enterobacteriaceae lainnya, Pseudomonas aeruginosa, dan Candida albicans (Hall K.K, \& Lyman J.A., 2006). Penelitian ini menghasilkan pertumbuhan Enterobacteriaceae dan Pseudomonas sp dengan proporsi positif pada kultur darah bifasik $22 \%$, sehingga bakteri hasil penelitian ini dianggap benar-benar sebagai bakteri penyebab bakteremia pada pasien tersangka demam.

E.coli dapat masuk kedalam peredaran darah dan menyebabkan sepsis, Klebsiella dapat menyebabkan infeksi lokal dan bakteremia pada pasien yang lemah. Serratia dapat menyebabkan bakteremia terutama pada pasien yang dirawat di rumah sakit, Pseudomonas dapat memasuki aliran darah dan menyebabkan sepsis yang fatal (Jawezt et al.,2010). Bakteremia dan sepsis yang disebabkan bakteri-bakteri tersebut dapat menyebabkan demam seperti pada pasien demam, sehingga dalam penelitian ini didapatkan hasil ditemukan bakteri selain Salmonella.

Organisme yang ditemukan mewakili kontaminasi dalam kultur darah menurut Hall K.K, \& Lyman J.A. (2006) adalah termasuk Staphylococcus koagulase-negatif, Corynebacterium sp, Bacillus sp selain Bacillus anthracis, Propionibacterium acnes, Micrococcus sp, Streptokokus viridans, Enterococci, dan Clostridium perfringens. Bakteri yang juga ditemukan sebagai kontaminan pada penelitian ini adalah Staphylococcus koagulase-negatif, Corynebacterium sp, Bacillus sp.

Kontaminasi dapat berasal karena pengambilan sampel yang tidak steril, pada penelitian ini pengambilan sampel pasien demam tidak dilakukan langsung oleh Peneliti tetapi dilakukan oleh analis di RSUD Ratu Zalecha. Kontaminasi yang ditemukan pada kultur darah dengan media bifasik sesuai dengan penelitian Parikh et al.,(2012) juga menyebutkan kontaminasi kultur darah konvensional dengan menggunakan media TSB $(7,0 \%)$ lebih banyak dibandingkan kultur dengan metode sentrifugasi lisis $(0,5 \%)$.

\section{Hasil Uji Serologi Widal}

Uji Widal dengan hasil negatif palsu dapat terjadi jika darah yang dikumpulkan terlalu awal stadium penyakit, karena itu, hasil negatif tidak mengesampingkan demam dan dapat digunakan sebagai dasar untuk titrasi komparatif berikutnya. Hasil positif palsu dapat dikaitkan dengan pemberian imunisasi demam dan adanya reaksi silang antibodi (Wain \& Hosoglu, 2008)

Penelitian yang dilakukan oleh Benedikt Ley (2010) juga telah melaporkan adanya reaksi silang antibodi pada uji widal dengan bakteri Klebsiella sp dan Staphylococcus sp.

Bakteri S. typhi merupakan bakteri batang Gram negatif yang komponen selnya sama dengan bakteri batang gram negatif yang lain, seperti E. coli, Ser. marcescens, Enterobacter cloacae, Klebsiella pneumoniae (Damayanti S, et al., 2012). Lipopolisakarida merupakan komponen struktural utama permukaan dari membran luar bakteri Gramnegatif, dan komponen enterobacteria terdiri dari lipid $\mathrm{A}$, daerah inti (core region), dan antigen $\mathrm{O}$ terdapat dalam banyak bakteri. Reaktivitas silang antibodi disebabkan oleh epitop umum yang terletak di daerah inti (inner core region) dari LPS ini (Loennies, et al., 2003).

\section{KESIMPULAN}

Hasil mikroskopis pewarnaan Gram buffy coat dibanding hasil kultur darah agar bifasik mempunyai nilai sensitifitas $67 \%$ dan spesifisitas $86 \%$.

\section{DAFTAR PUSTAKA}

Alfred Young Itah and Edet Ekpo Uweh. (2005). 'Bacteria isolated from blood, stool and urine of typhoid patients in a developing country'. Southeast Asian J Trop Med Public Health, Vol 36, No. 3, pp. 673-677. 
Amarantini, C., W. Asmara, H. Kushadiwijaya \& L. Sembiring. (2009). 'Seleksi Bakteri Salmonella typhi dari Kultur Darah Penderita Demam Tifoid'. Prosiding Seminar Nasional Penelitian, Pendidikan dan Penerapan MIPA. Fakultas MIPA. Universitas Negeri Yogyakarta. ISBN: 978-979-96880

Ashkenazy, S., Cleary, TG. (2000). Infeksi Salmonella.. Dalam: Wahab, AS, penyunting. IImu kesehatan anak nelson, EGC, Vol.II. Edisi.15, Jakarta

Bakr, WM., Attar, LA., Ashour, MS., Toukhy, AM. (2011). 'The dilemma of widal testwhich brand to use? A study of four different widal brand: a cross sectional comparative study'. Ann clin microb, Vol.10. No.7

Bearman, GM., Wenzel, RP. (2005). Bacteremias: a leading cause of death. Arch Med Res, Vol. 36, pp. 646-659

Benedikt Ley, George Mtove, Kamala Thriemer, Ben Amos, Lorenz von Seidlein, Ilse Hendriksen, Abraham Mwambuli, Aikande Shoo, Rajabu Malahiyo, Shaali M Ame, Deok R Kim, Leon R Ochiai, John D Clemens, Hugh Reyburn, Harald Wilfing, Stephen Magesa and Jacqueline L Deen. (2010). 'Evaluation of the Widal tube agglutination test for the diagnosis of typhoid fever among children admitted to a rural hdospital in Tanzania and a comparison with previous studies', BMC Infectious Diseases, Vol.10, No.180

Bergey, David, H., John, G., Holt, Noel, R., Krieg, Peter, H.A., Sneath. (1994). Bergey's manual of determinative bacteriology. Edisi. 9th

CDC. (2010). Thypoid fever, national center for emerging and zoonotic infectious diseases, USA, http://www.cdc.gov/nczved/ divisions/dfbmd/diseases/typhoid_fever/

Choo, KE., Lim, WY., Razif, AR., Ariffin, WA., Oppenheimer, SJ., Abraham, T. (1992). Usefulness of the Widal test in childhood typhoid fever. Dalam : Pang T, Koh CL, Puthucheary SD, Eds. Typhoid Fever : Strategies for the 90's. Singapore : World Scientific. pp 200.

Departemen Kesehatan Republik Indonesia. (2008). Profil kesehatan Indonesia,
Jakarta.

Gura, KM., (2004). Incidence and nature of epidemic nosocomial infections. J Infus Nurs Vol. 27. pp. 175-180

Haque, A., Ahmed, J., Qureshi, JA. (1999), 'Early detection of typhoid by polymerase chain reaction', Ann Saudi Med, Vol. 19, No.4, pp. 337-40

Harshal, R., Parikh, Anuradha, S., De, Sujata, M., Baveja. (2012). 'Comparison of the lysis centrifugation method with the conventional blood culture method in cases of sepsis in a tertiary care hospita'l, Journal of Laboratory Physicians, Vol. 4, No. 2, pp. 89-93

Jawetz, Melnick, Adelberg's. (2010), Medical Mikrobiology.

John Wain, Salih Hosoglu. (2008).' The laboratory diagnosis of enteric fever', J Infect Developing Countries, Vol. 2, No.6, pp. 421-425

Karsinah, Suharto, W. Mardiastuti, M. Lucky. (1994). Batang negatif gram. Dalam: Staf Pengajar FK UI, penyunting, Buku ajar mikrobiologi kedokteran, Edisi Revisi, Bina Rupa Aksara, Jakarta, pp.168-73,.

Kung, H., Hoyert, DL., Xu, J., Murphy, SL. (2008). Deaths data for 2005, Natl Vital Stat Rep, Vol. 56, pp. 1-121.

Massi, MN., Shirakawa, T., Gotoh, A., Bishnu, A., Hatta, M., Kawabata, M. (2003), 'Rapid diagnosis of typhoid fever by PCR assay using one pair of primers from flagellin gene of Salmonella typhi, $J$ Infect Chemother, Vol.9, No.3, pp 233-7.

Mette Sogaard. Mette Norgaard. Claus Dethlefsen. and Henrik Carl Schonheyder. (2013). 'Temporal changes in the incidence and 30-day mortality associated with bacteremia in hospitalized patients from 1992 through 2006: a populationbased cohort study', Oxford Journals Clinical Infectious Diseases, Vol. 52, No. 1, pp. 61-69.

Muliawan, SY., Surjawidjaya, JE. (1999). Diagnosis dini demam tifoid dengan menggunakan protein membran luar $S$. Typhi sebagai antigen spesifik. CDK, pp. 11-3. 
Odetola, FO., Moler, FW., Dechert, RE., VanDerElzen, K., Chenoweth, C. (2003). Nosocomial catheter-related bloodstream infections in a pediatric intensive care unit: risk and rates associated with various intravascular technologies. Pediatr Crit Care Med, Vol. 4, pp. 432436

Parry, CM. (2002). Typhoid fever. N Engl J Med, Vol. 347, No. 22

Patrick, R., Murray, Ellen jabaron, James, H., Jorgensen, Marie Louise Landry, Michael, A., Praller. (2007). Manual of clinical microbiology $9^{\text {th }}$ Edition, ASM press, American Socielity for Microbiology, Washington DC

Pawitro, UE., Noorvitry, M., Darmowandowo, W. (2002). Demam tifoid. Dalam : Soegijanto S, Ed. IImu penyakit anak: diagnosa dan penatalaksanaan, Salemba Medika, edisi.1, pp.1-43, Jakarta.

Richmond, C., Reyes., M.D., Emmanuel Edwin, R., Dy, M.D., and Shirley Cresswell, HCLD. (2002). The utility of buffy coat Gram stain for the detection of bacteremia in patients with sepsis', Phil $J$ Microbiol Infect Dis, Vol. 31, No. 2, pp. 70-73

Sabiha al- joubori. (2006). 'Buffy coat smear and culture: An early diagnostic procedure in bacteremic and septicemia Pediatric Patients', Mustansiriya Medical Journal, Vol. 6, No. 1, pp. 7-14

Segal, G.S., Chamberlain, J.M. (2000). Resource utilization and contaminated blood cultures in children at risk for occult bacteremia. Arch Pediatr Adolesc Med, Vol. 154, pp. 469-473

Shafazand, S., Weinacker, A.B. (2002). Blood cultures in the critical care unit: improving utilization and yield. Chest, Vol.122, pp.1727-1736

Sharon, M., Tennant, Mary, A., Boyd, Deanna Toema, Johan Melendez, Yongxia Zhang, James, E., Galen, Chris, D., Geddes and Myron, M., Levine. (2013). 'New diagnostic approaches to detect Salmonella spp. in blood', 8th International Conference on Typhoid Fever and Other Invasive Salmo- nellose, Speaker abstracts, Dhaka, Bangladesh.

Skogberg, K., Lyytikäinen, O., Ruutu, P., Ollgren, J., Nuorti, J.P. (2008), 'Increase in bloodstream infections in Finland 1995 -2002', Epidemiol Infect, Vol. 136, pp.108 $-114$.

Sogaard, M., Norgaard, M., Schonheyder, H. (2007). 'First notification of positive blood cultures: high accuracy of the Gram stain report (Epub ahead of publication)'. J Clin Microbiol, Vol. 45, No.4, pp. 1113-7.

Sri Darmawati, Langkah Sembiring, Widya Asmara, Wayan, T., Artama. (2012). 'Keanekaragaman spesies bakteri pada kultur darah widal positif asal kota Semarang berdasarkan karakter fenotipik'. Seminar Nasional ix Pendidikan Biologi FKIP UNS, pp 496-501

Stanley Lemeshow, David, W., Hosmer, Jr., Jenelle Klar and Stephan, K., Lwanga. (1990). Adequacy of sample size in health studies, WHO

Sven Müller-Loennies, Lore Brade, C., Roger MacKenzie, Franco, E., Di Padova. (2003). 'Helmut Brade, Identification of a Cross-reactive Epitope Widely Present in Lipopolysaccharide from Enterobacteria and Recognized by the Cross-protective Monoclonal Antibody WN1 222-5'. Journal of Biological Chemistry, No. 278, pp. 25618-25627

Tumbelaka, A.R., (2005). Tata laksana terkini demam tifoid pada anak. Simposium Infeksi-Pediatri Tropik dan Gawat Darurat pada Anak. IDAI Cabang Jawa Timur. Malang, IDAI Jawa Timur, pp.3750.

Uslan, D.Z., Crane, S.J., Steckelberg, J.M. (2007).' Age- sex-associated trends in bloodstream infection: a population-based study in Olmsted County, Minnesota', Arch Intern Med, Vol.167, pp.834-839.

Wain, J., Bay, PVB., Vinh, H., Duong, N.M., Diep, T.S., Walsh, A.L., et al. (2001). 'Quantitation of bacteria in bone marrow from patients with typhoid fever: relationship between counts and clinical features', J Clin Microbiol, Vol. 39, No. 4, pp. 1571-6. 